\title{
PLEISTOCENE PALAEOCLIMATIC EVOLUTION FROM AGIOS GEORGIOS CAVE SPELEOTHEM (KILKIS, N. GREECE)
}

\author{
Dotsika E. ${ }^{1}$, Psomiadis D. ${ }^{1}$, Zanchetta G. ${ }^{2}$, Spyropoulos N. ${ }^{3}$, Leone G. ${ }^{2}$, \\ Tzavidopoulos I. ${ }^{1}$ and Poutoukis D. ${ }^{4}$ \\ ${ }^{1}$ Stable Isotope Unit, Institute of Materials Science, NCSR Demokritos, Agia Paraskevi Attiki, Greece, \\ edotsika@ims.demokritos.gr,dapsom@ims.demokritos.gr,itzav@ims.demokritos.gr \\ ${ }^{2}$ Dipartimento di Scienze della Terra, University of Pisa, Via S. Maria 53, 56126 Pisa Italy, \\ zanchetta@dst.unipi.it \\ ${ }^{3}$ Greek Ministry of Development, Mesogion 119, 10192 Athens, Greece \\ ${ }^{4}$ General Secretariat for Research and Technology, Mesogion 14-18, 11510 Athens, Greece, \\ dpoutoukis@gsrt.gr
}

\begin{abstract}
Palaeoclimatic reconstruction in N. Greece has been investigated in this study, using stable isotope analyses and U/Th dating of a speleothem (stalactite) from the cave of Agios Georgios (Kilkis). Sampling sequence was followed in detail in order to obtain high resolution analysis of the proxy. Speleothem $\delta^{18} \mathrm{O}$ entirely depends on two factors: changes in the $\delta^{18} \mathrm{O}$ of the percolation waters (a proxy for local rainfall $\delta^{18} \mathrm{O}$ ) and the temperature of water-calcite fractionation inside the cave (a proxy for outside air temperatures). During periods of relatively stable temperatures, $\delta^{13} \mathrm{C}$ shifts are caused principally by variations in soil $\mathrm{CO}_{2}$ input and physico-chemical processes inside the cave. More important processes affect the $\delta^{13} \mathrm{C}$ signal of speleothem inside the cave are length of flow path and rates of $\mathrm{CO}_{2}$ degassing.The lower $\delta^{13} \mathrm{C}$ calcite values indicate greater respiratory activity of soils under wetter conditions. The stalagmite layers were dated through U/Th geochronological method, which places the carbonate precipitation in Middle Pleistocene (630-300ka BP). The isotopic composition of the layers was used in combination with the dating results to reconstruct the evolution of the area of Kilkis. Correlation with global climatic records shows that major climatic transitions that influenced northern hemisphere seem to have also affected the region of $N$. Greece.
\end{abstract}

Key words: speleothem, stable isotopes, palaeoclimate, Pleistocene, Macedonia, Greece.

\section{Introduction}

Speleothems are probably the most interesting formations of limestone caves, because they hold a remarkable archive of palaeoclimatic data describing local and global events for the period of time in which they grew. As calcite nucleates on the surface of the growing cave formation, trace elements and certain isotopes are sealed in place, in concentrations that may bear similarity to the environmental conditions under which they have formed. A climatic record can be derived from the relative contents of ${ }^{13} \mathrm{C}$ and ${ }^{18} \mathrm{O}$ in the lattice. Support for a palaeoclimatic record based on growth frequencies of speleothems can be obtained from the dated deposits themselves, by variations in ${ }^{13} \mathrm{C}$ and ${ }^{18} \mathrm{O}$ 
of calcite along the growth axes of deposits that formed in isotopic equilibrium with the groundwater (Gascoyne, 1992).

Our understanding of palaeoclimatic transitions has been considerably increased by the many recent studies of global climatic change (e.g. Imbrie et al., 1984; Chappell and Shackleton, 1986; Bond et al., 1993; Dansgaard et al., 1993; Bar-Matthews et al., 1997). Eastern Mediterranean region is a transition zone between humid climate in the north and arid climate in the south. As in other climatic transition zones, the region of north Aegean Sea was sensitive in the past to changes in natural environmental parameters, such as temperature, amount of rainfall, origin and pattern of storm tracks, vegetation type, and location of the desert boundary (Street and Grove, 1979; Bar-Matthews 1999; Tzedakis et al., 2003; Geraga et al., 2005; Hughes et al., 2007; Psomiadis et al., 2009).

It has long been appreciated that, at least for the last $450 \mathrm{ka}$, the many stages and substages into which the deep-sea isotopic sequence is divided are also appropriate for viewing the continental record (e.g. Shackleton, 1969; Tzedakis et al., 1997, 2001, 2003), although marine and terrestrial boundaries may not be precisely isochronous. With regard to the amplitude of climate variability, research focusing has been developed over some prominent transitions during the Middle Pleistocene, like the so-called Mid-Brunhes Event (MBE) at the MIS 11/12 transition ca. $430 \mathrm{ka}$ (EPICA community members, 2004), the most severe glacial period correlated to MIS 12 (Tzedakis et al., 2003), the moderate variations during MIS 13-15 etc. Regarding palaeoclimatic data for the region of Greece during Middle Pleistocene, studies have been applied to pollen analysis (Tzedakis et al., 2003, 2006) and geomorphological and sedimentary data (e.g. Hughes et al., 2007). These studies have indicated that the most severe tree population contractions of the last $450 \mathrm{ka}$ occurred during the glacial maxima of MIS 12 and less intense MIS 10 (Tzedakis et al., 2003, 2006). These results were in agreement with the relative extent of ice sheets as estimated from marine benthic isotope records (e.g. Shackleton, 1987; Waelbroeck et al., 2002) and reconstructed from field evidence from Europe (e.g. Ehlers, 1996). During the most extensive Skamnellian Stage glaciation (MIS 12), climate would have been even colder and/or wetter than was the case for both the later Vlasian and Tymphian cold stages (Hughes et al., 2007). MIS 16 appears to be the most extensive glacial period of the last 1.35Ma, not in terms of intensity but rather of the prolonged suppression of tree populations (Tzedakis et al., 2006).

Early middle Pleistocene faunas seem to be missing from Greece. In central-western Europe this period is characterized by a new warm phase of alternations of mild glacial intervals with warm interglacial ones (Agusti and Anton, 2002). From middle Pleistocene onwards, the establishment of the bipolar climate in the North Alpine areas forced the south European environment to alternate between Mediterranean arid and mild-temperate (Kostopoulos and Vasileiadou, 2006).

In the present work, a ca. $250 \mathrm{ka} \delta^{18} \mathrm{O}$ and $\delta^{13} \mathrm{C}$ record that was obtained from a stalactite from northern Greece (Agios Georgios Cave, Kilkis) are discussed for palaeoclimatic interpretation during the period from MIS $9 \mathrm{~b}$ to MIS15e.

\section{Setting of the area}

Agios Georgios cave is located near the city of Kilkis (Fig. 1), approximately 50km north of Thessaloniki (Macedonia, N. Greece). The total length of its hallways is $500 \mathrm{~m}$ and its total surface reaches up to $1000 \mathrm{~m}^{2}$. The internal environment is typical of a karstic cave, with stable temperature all year round $\left(16 \pm 1^{\circ} \mathrm{C}\right)$ and high humidity $(95 \%)$. Mean annual precipitation in the region is $386 \mathrm{~mm}$ and mean annual temperature is equal to $15.1^{\circ} \mathrm{C}$. 

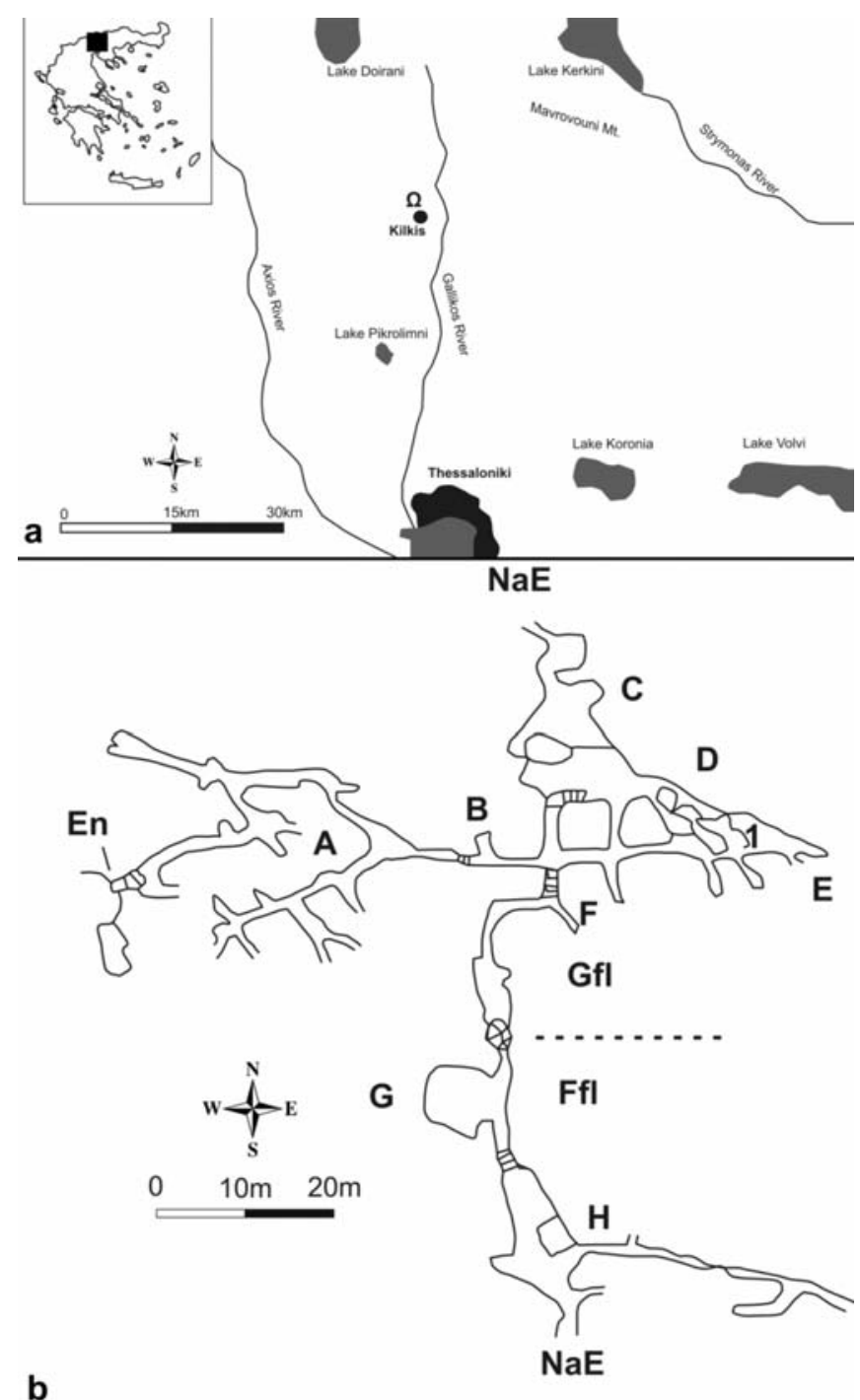

Fig. 1: Location of the study site (a) and ground plan (b) of Agios Georgios cave $(\Omega)$. NaE: Natural Entrances; En: Entrance of the cave; Gfl: Ground floor; FFl: First floor; A-H: Chambers; 1: Sampling position of stalactite SP4.

The karst has been developed in the M.-U. Triassic limestone (Kockel and Ioannides, 1979). Palaeontological evidence recorded several species of mammals and micromammals of the last $15 \mathrm{ka}$ (Tsoukala, 1991).

\section{Methods}

\subsection{Sampling and isotopic analyses}

The cave conditions and processes render the specific environment as a partly active (humid) karst setting (Woodward and Goldberg, 2001) with on-going drip-flow in only some of the cham- 


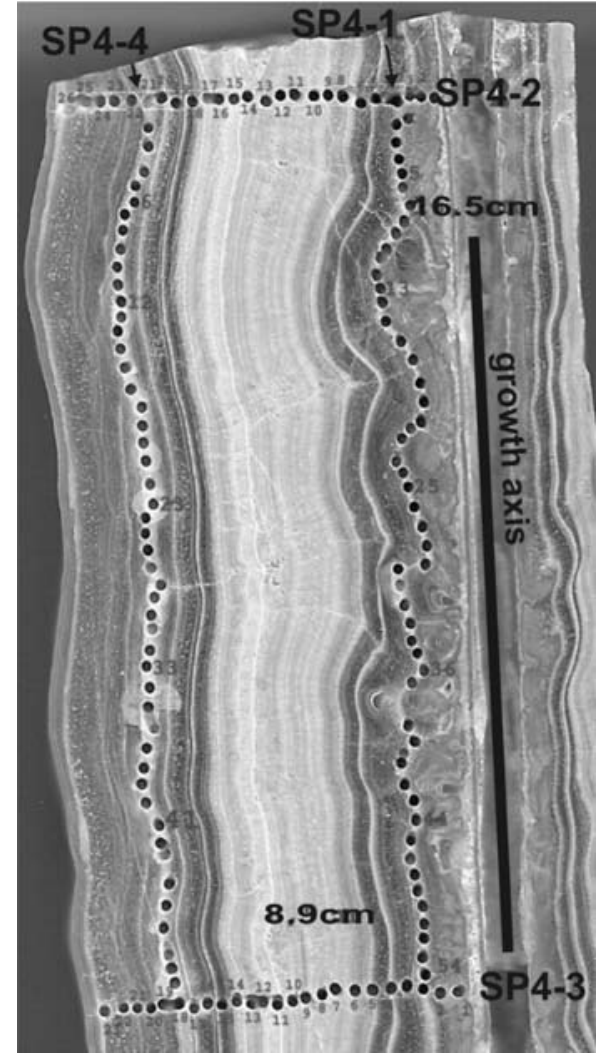

Fig. 2: Cut section of SP4. SP4-2 and SP4-3 are perpendicular subsampling sections to the growth axis. SP41 and SP4-1 are parallel subsampling sections, respective to layers 3 and 21 (dating samples and Hendy tests).

bers. A stalactite (SP4, 181 mm long and 56mm wide) was selected for isotopic analysis from deep within the cave (chamber D, Fig. 1). SP4 generally kept to all necessary conditions for isotopic analysis (Hendy, 1971) which mainly are a deep spot in the cave, not very close to air-circulation exits (i.e., cave entrance) and not in very high chambers (the distance of the drip water during its falling from the cave ceiling may induce isotopic fractionation). The sampled stalactite was cut perpendicular to its length in order to expose their growth laminae and to permit observation and subsampling. To obtain high resolution $\delta^{18} \mathrm{O}$ and $\delta^{13} \mathrm{C}$ records, the laminae were sampled every $2 \mathrm{~mm}$ by means of microdrilling, using a $0.7 \mathrm{~mm}$ diameter drill bit (Fig. 2) providing approximately $300-500 \mu \mathrm{g}$ of carbonate powder.

Two subsampling sections parallel to the growth axis (SP4-2 and SP4-3) were used in order to examine the palaeoclimatic variability during the growth of the stalactite, whereas two other subsampling sections perpendicular to the growth axis and representing specific laminae (SP4-1 and SP4-4) were used for the radiometric datings and for the application of the so-called Hendy tests (see below). In total, 126 subsamples were extracted for isotopic analyses and dating. $\delta^{13} \mathrm{C}$ and $\delta^{18} \mathrm{O}$ isotopic ratios of the calcitic stalactite layers were measured (vs. PDB standard) on a Thermo Delta V Plus isotope ratio mass spectrometer equipped with a GasBench II device at Stable Isotope Unit, I.M.S., NCSR Demokritos, Athens, after addition of $\mathrm{H}_{3} \mathrm{PO}_{4}$ for $\mathrm{CO}_{2}$ production at $72^{\circ} \mathrm{C}$ (Fig. 3). The standards used for comparison were NBS 19 and NBS 18 carbonates and an internal Carrara marble standard. 
SP4-2 and SP4-3 carbon isotope

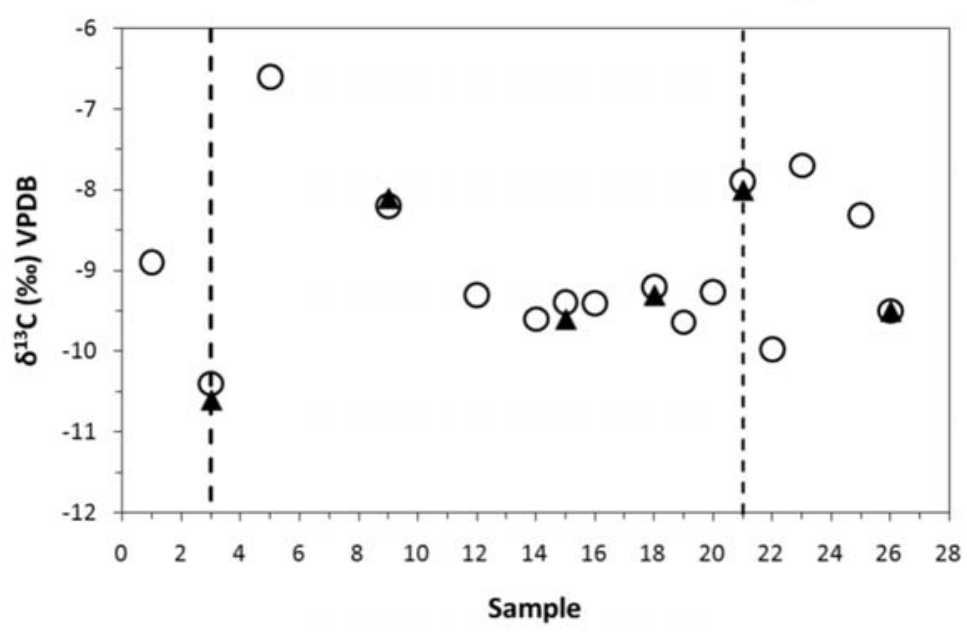

SP4-2 and SP4-3 oxygen isotope

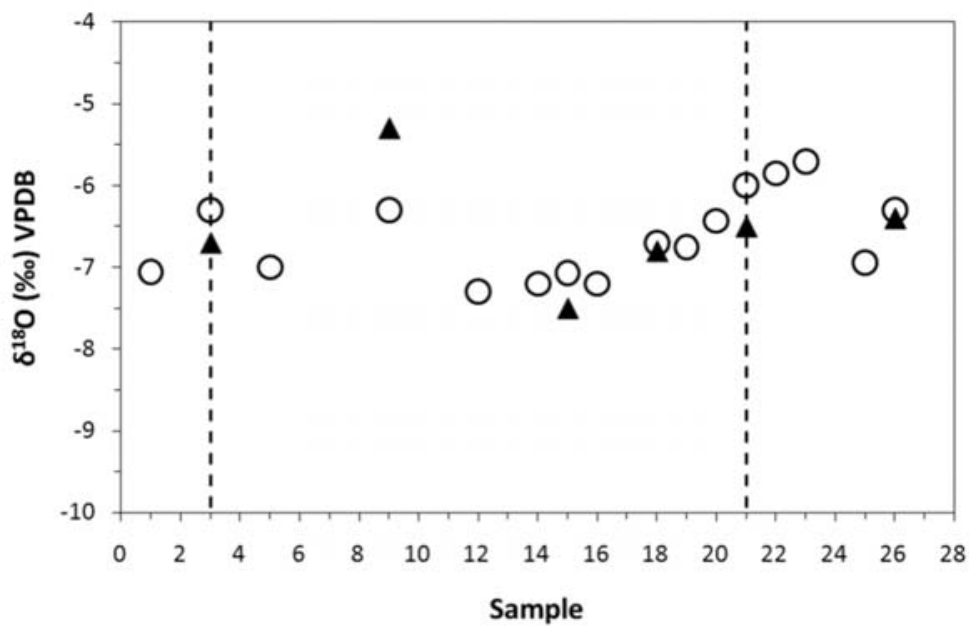

Fig. 3: Results of isotopic measurements (VPDB): variation of carbon and oxygen isotopes across sampling sections. Circles: SP4-2; Black triangles: SP4-3. Dashed-lines represent the U/Th datings of laminae 3 and 21.

Analytical reproducibility is better than $0.1 \%$ for $\delta^{13} \mathrm{C}$ and $\delta^{18} \mathrm{O}$. Uranium-series dating was performed using thermal ionization mass spectrometry (TIMS). For the analyses, approximately $200 \mathrm{mg}$ samples were used from the two sections (SP4-1 and SP4-4). Ages for each position were determined using a Fisons VG Sector 54-30 mass spectrometer equipped with a WARP filter and an ioncounting Daly detector. Full analytical details of the TIMS method are provided in Zhao et al. (2001).

Isotopic fractionation was excluded after conducting the proposed tests by Hendy (1971) along two specific layers of the stalactite (SP4-1 and SP4-4), which showed negligible kinetic effects (Fig. 4). The $\delta^{18} \mathrm{O}$ values along individual laminae are generally constant, whereas $\delta^{13} \mathrm{C}$ values vary up to $1.8 \%$ and are not correlated with $\delta^{18} \mathrm{O}$. 


\section{"Hendy" test - SP4-1}

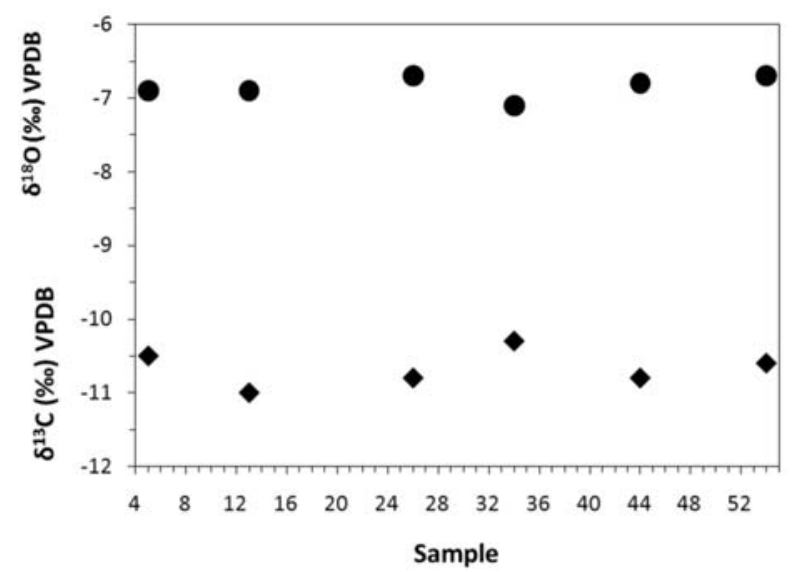

"Hendy" test - SP4-4

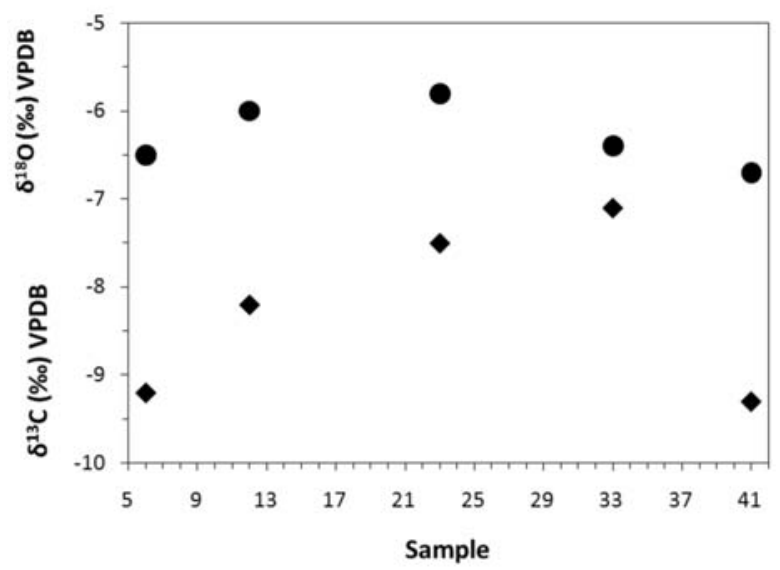

Fig. 4: Plots showing the $\delta^{18} \mathrm{O}$ and $\delta^{13} \mathrm{C}$ variations (VPDB) for representative different laminae (SP4-1 and SP44) of SP4 stalactite as measured along the length of the laminae (see also figure 2). The isotopic trends indicate minor variations in $\delta^{18} \mathrm{O}$ and wider variations in $\delta^{13} \mathrm{C}$. These trends are in accordance with suggested criteria for isotopic equilibrium (Hendy, 1971).

\subsection{Results and discussion}

Variations in $\delta^{13} \mathrm{C}$ of cave deposits could be attributed to: i) length of flow path and rates of $\mathrm{CO}_{2}$ degassing which favour speleothem $\delta^{13} \mathrm{C}$ enrichment when the surface recharge is low under drier environment; ii) greater respiratory activity of soils under wetter conditions resulting in lower $\delta^{13} \mathrm{C}$ calcite values; iii) biogenic $\mathrm{CO}_{2}$ (lighter values-warmer climate) vs. atmospheric $\mathrm{CO}_{2}$ (heavier values-cooler climate; McDermott, 2004). Respectively, oxygen isotopic composition of stalagmites may vary due to: i) evaporation effect during arid climatic conditions accompanied by enrichment in $\delta^{18} \mathrm{O}$; ii) amount effect i.e. augmented rainfalls, resulting in $\delta^{18} \mathrm{O}$ decrease in meteoric water (Rozanski et al., 1993; Bard et al., 2002; Straight et al., 2004); iii) lower deposition temperatures resulting in higher $\delta^{18} \mathrm{O}$ values in carbonate precipitations (Gascoyne, 1992; Bar- 
Matthews et al., 1996; McDermott, 2004).

It has long been established that for the last 900ka the many subdivisions into which the deep-sea isotopic sequence is divided are reliable for viewing the continental record like speleothems (e.g. Shackleton, 1969; Tzedakis et al., 1997, 2003, 2006), although marine and terrestrial boundaries may not be precisely isochronous. U-series dating of SP4 indicates that the formation of this stalactite started after the Middle Pleistocene Transition (920-640ka BP) and ceased during MIS 9 (ca. 300ka BP). Inspection of figure 5 reveals a close correspondence between variations in global marine isotopic data and the isotopic signature of SP4. In this study, the composite $\delta^{18} \mathrm{O}_{\text {benthic }}$ record from the equatorial East Pacific (Shackleton et al., 1983; Ninkovich and Shackleton, 1975; Shackleton et al., 1990) and the EPICA Dome $C$ record in Antarctica (EPICA community members, 2004) have been used for intercomparison. These data series have been well correlated to climatic variations in the region of Greece by Tzedakis et al. (2006). Minor discrepancies are at all occasions within the analytical error $(2 \sigma)$ of dating results. However, although major climatic events recorded in marine records seem to have influenced also the region of N. Greece, some well-established climatic periods do not correspond to alterations of the isotopic composition of SP4 calcitic laminae. The latter may be attributed either to the absence of these phases in the region or to depositional factors related to rates of carbonate accumulation or to cave conditions.

The palaeoclimatic interpretation of SP4 isotopic record (Fig. 3 and 5) shows high resolution correlation with five interglacial and four glacial periods during the Middle Pleistocene. The earliest stage corresponds to MIS 15e (lamina 1, 630-610ka BP) with moderately warm conditions, followed by the cooler short stadial MIS 15d (lamina 3, 610-600ka BP). MIS 15d have influenced N. Greece with lower temperatures but as it seems by the depleted $\delta^{13} \mathrm{C}$ the climate was rather humid than permafrost. MIS 15a (lamina 5, 580-570ka BP) restored warmer conditions in the region but the recorded enriched $\delta^{13} \mathrm{C}$ indicates absence of soil coverage and biological activity, which probably renders this lamina to the transition between MIS $15 \mathrm{a} / 15 \mathrm{~b}$. Lamina 9 clearly represents low temperatures and arid conditions (enriched $\delta^{18} \mathrm{O}$ and $\delta^{13} \mathrm{C}$ ) and correlates well to MIS 14 (540-500ka $\mathrm{BP})$, which influenced temporally the region in accordance to global records. SP4 laminae 12-19 show an explicit climatic stability in both $\delta^{18} \mathrm{O}$ and $\delta^{13} \mathrm{C}$. According to U-series dating, these laminae correspond to the time window between 490-390ka BP and indicate warm and wet climate. The effectual correlation of this period with MIS 13 (ca. 480ka BP) and MIS 11 (ca. 400ka BP) is opposed to the absence of isotopic record in SP4 correlated to the most severe Middle Pleistocene glacial MIS 12 (ca. 450ka BP) or to the so-called Mid-Brunhes Event at ca. 430ka BP, also recorded in Greece. During MIS 12, the coldest mean summer temperatures and the local glacier maximum were recorded in the region (Hughes et al., 2007) and also arboreal pollen reached their minimum in N. Greece (Tzedakis et al., 2006). However, the absence of MIS 12 climatic transition in SP4 could be attributed to ceased stalactite growth due to permafrost conditions in the soil surface, which is a typical factor of speleothems hiatuses due to the crucial decrease of water flow and drip rates.

A mild alteration of the climatic conditions took place in lamina 20 (390-360ka BP) which probably corresponds to the transition between MIS 11 and MIS 10 , indicated by the slightly enriched $\delta^{18} \mathrm{O}$ (cooler climate). The establishment of the glacial conditions of MIS 10 seems to have happened at $360 \mathrm{ka} \mathrm{BP}$ and held until 340ka BP (laminae 21-23). This period is characterized by cool and dry climate, interposed by a cold and wet phase at 350ka BP (lamina 22), which by any means does not change the glacial character of MIS 10 in N. Greece, but it rather indicates a short abatement of the frost coverage of the epikarst. This interruption is also indicated in arboreal pollen from N. Greece (Tzedakis et al., 2006) and also in isotopic records from Antarctica (EPICA community members, 


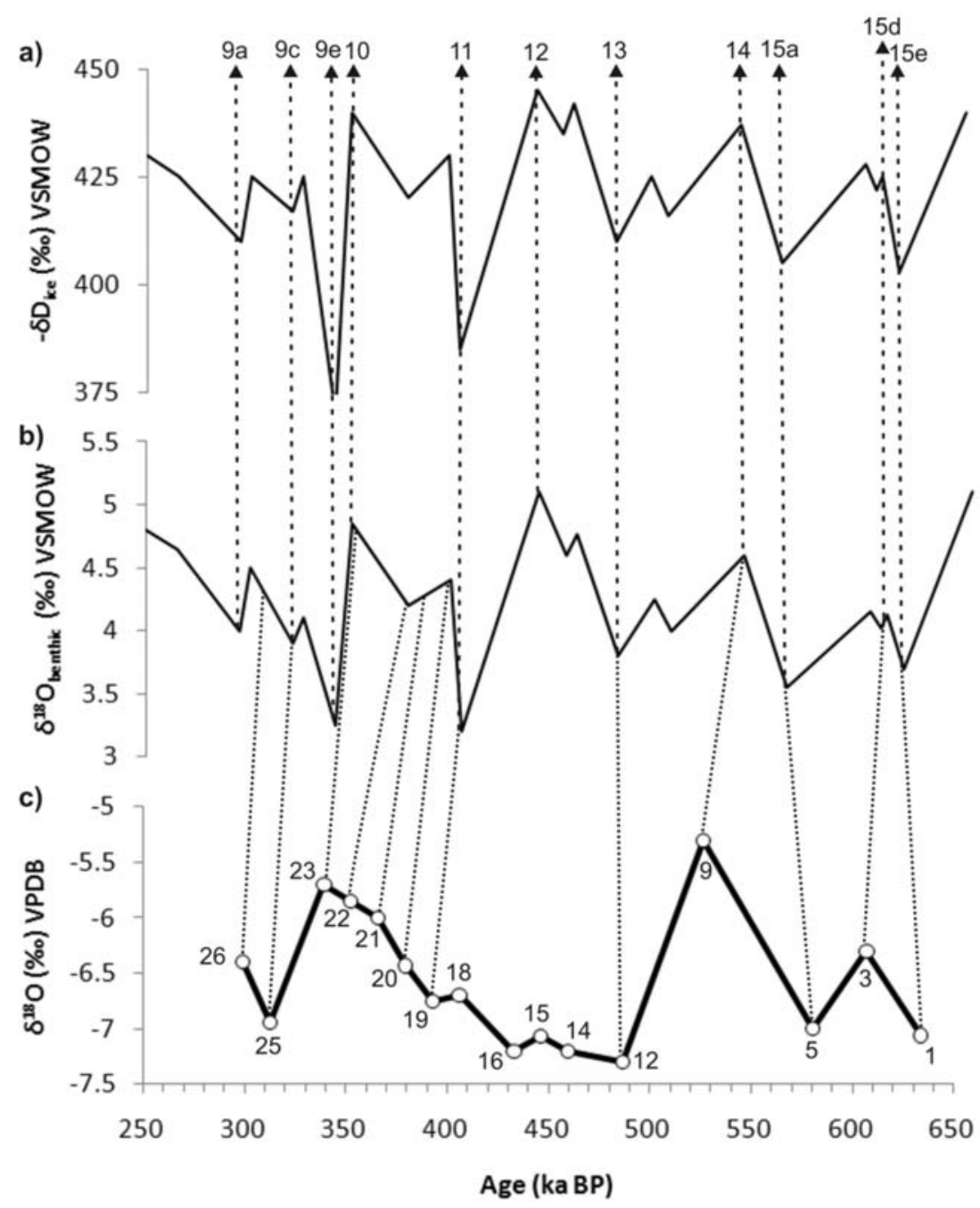

Fig. 5: a) EPICA Dome C (EDC), Antarctica, Deuterium ( $-\delta D)$ record (EPICA community members, 2004); b) $\delta^{18}$ Obenthic composite record from sites in the equatorial East Pacific (Shackleton et al., 1983; Ninkovich and Shackleton, 1975; Shackleton et al., 1990); c) SP4 $\delta^{18}$ O record, with the respective sampling laminae. On top of the diagram, the Marine Isotope Stages are indicated. Dense-dashed lines connecting b) and c) represent the palaeoclimatic correlation of SP4 with global records (see text for interpretation).

2004). The following warming occurred at 320-310ka BP (lamina 25). This stage, although it should be expected to meet with MIS 9e due to sequence, probably corresponds to the milder MIS 9c with warm and arid climate. This assumption is based on the fact that lamina 25 does not show the acute transition of climatic conditions that characterizes MIS $9 \mathrm{e}$ and also on the age position in SP4 stratigraphy. The absence of MIS 9e intense warming in SP4 is attributed to subsampling resolution, as it was quite short in duration and therefore may have not been isolated in laminae distinction. SP4 isotopic record ends with a cooler (enriched $\delta^{18} \mathrm{O}$ ) and rather humid (depleted $\delta^{13} \mathrm{C}$ ) stage, which corresponds well to the transition between MIS 9c and 9b (lamina 26, ca. 300ka BP). 


\section{Conclusions-Results}

The isotopic record of SP4 stalactite from Agios Georgios cave, Kilkis, N. Greece, has indicated several climatic transitions in the region. These alterations correlate well with marine records from around the world as well as with terrestrial palaeoclimatic data from Greece. According to these variations, SP4 record mirrors two cold and dry stages (MIS 14 and 10) and two warm and wet periods (MIS 11 and MIS 13). Among the above, several stadials and interstadials have been isotopically fingerprinted, showing that global climatic changes, which influenced mostly the northern hemisphere, have also influenced the area of N. Greece. The absence of two distinct climatic events in SP4 record, the severe cold MIS 12 and the intense warm MIS 9e, is attributed to different factors. The permafrost soil coverage during MIS 12 probably caused growth cease of the speleothems in Agios Georgios cave, while the short duration of MIS 9e may have caused slipping during subsampling. In any case, although higher resolution of subsampling and denser datings would offer the opportunity to distinguish shorter and more detailed climatic transitions, the study of SP4 isotopic record encourages the application of palaeoclimatic interpretations in speleothems around Greece.

\section{Acknowledgments}

The authors would like to thank Mr. Makridis V. for his guidance and help during sampling at Agios Georgios cave.

\section{References}

Agusti, J., Anton, M., 2002. Mammoths, Sabertooths, and Hominids. Columbia Univ. Press, pp. 313.

Bar-Matthews, M., Ayalon, A., Kaufman, A., 1997. Late Quaternary climate in the eastern Mediterranean region-inferences from the stable isotope systematics of speleothems of the Soreq cave (Israel). Quaternary Research $47.155-168$.

Bond, G., Broecker, W., Johnsen, S., McManus, J., Labeyrie, L., Jouzel, J., Bonani, G., 1993. Correlations between climate records from North Atlantic sediments and Greenland ice. Nature 365, 143-147.

Chappell, J., Shackleton, N.J., 1986. Oxygen isotope and sea level. Nature 324, 137-140.

Dansgaard, W., Johnsen, S.J., Clausen, H.B., Dahl-Jensen, D., Gundestrup, N.S., Hammer, C.U., Hvidberg, C.S., Steffensen, J.P., Sveinbjornsdottir, A.E., Jouzel, J., Bond, G., 1993. Evidence for general instability of past climate from a 250-kyr ice-core record. Nature 364, 218-220.

Ehlers, J., 1996. Quaternary and Glacial Geology. Wiley, Chichester.

EPICA community members, 2004. Eight glacial cycles from an Antarctic ice core. Nature 429, 623-628.

Hughes, P.D., Woodward, J.C., Gibbard, P.L., 2007. Middle Pleistocene cold stage climates in the Mediterranean: New evidence from the glacial record. Earth and Planetary Science Letters, 253 (1-2), 50-56.

Imbrie, J., Hays, J.D., Martinson, D.G., McIntyre, A., Mix, A.C., Morley, J.J., Piasias, N.G., Prell, W.L., Shackleton, N.J., 1984. The orbital theory of Pleistocene climate: Support from a revised chronology of the marine $\delta^{18} \mathrm{O}$ record. In: A.L. Berger et al. (Eds.), Milankovitch and Climate, Part I. Reidel, Dordrecht, pp. 269-305.

Kostopoulos, D., Vasileiadou, K., 2006. The Greek Late Neogene-Quaternary ursids in relation to palaeogeography and palaeoenvironment. Scientific annals, School of Geology, Aristotle University of Thessaloniki 98, 285-292.

Ninkovich, D., Shackleton, N.J., 1975. Distribution, stratigraphic position and age of ash "L" in the Panama Basin region. Earth and Planetary Science Letters 27, 20-34.

Psomiadis, D., Dotsika, E., Zisi, N., Pennos, C., Pechlivanidou, S., Albanakis, K., Syros, A., Vaxe- 
vanopoulos, M., 2009. Geoarchaeological study of Katarraktes cave system: Isotopic evidence for environmental alterations. Géomorphologie : relief, processus, environnement, in press.

Shackleton, N.J., 1969. The last interglacial in the marine and terrestrial records. Proceedings of the Royal Society, London B 174, 135-154.

Shackleton, N.J., 1987. Oxygen isotopes, ice volume and sea level. Quaternary Science Reviews 6, 183-190.

Shackleton, N.J., Imbrie, J., Hall, M.A., 1983. Oxygen and carbon isotope record of East Pacific core V19-30: implications for the formation of deep water in the late Pleistocene North Atlantic. Earth and Planetary Science Letters 65, 233-244.

Shackleton, N.J., Berger, A., Peltier, W.R., 1990. An alternative astronomical calibration of the Lower Pleistocene timescale based on ODP Site 677. Transactions of the Royal Society of Edinburgh: Earth Sciences 81, 251-261.

Street, F.A., Grove, A.T., 1979. Global maps of lake-level fluctuations since 30,000 yr B.P. Quaternary Research 12, 83-118.

Tzedakis, P.C., Andrieu, V., de Beaulieu, J.-L., Crowhurst, S., Follieri, M., Hooghiemstra, H., Magri, D., Reille, M., Sadori, L., Shackleton, N.J., Wijmstra, T.A., 1997. Comparison of terrestrial and marine records of changing climate of the last 500,000 years. Earth and Planetary Science Letters 150,171-176.

Tzedakis, P.C., Andrieu, V., Birks, H.J.B., de Beaulieu, J.-L., Crowhurst, S., Follieri, M., Hooghiemstra, H., Magri, D., Reille, M., Sadori,L., Shackleton, N.J., Wijmstra, T.A., 2001. Establishing a terrestrial chronological framework as a basis for biostratigraphical comparisons. Quaternary Science Reviews 20, 1583-1592.

Tzedakis, P.C., McManus, P.C., Hooghiemstra, H., Oppo, D.W., Wijmstra, T.A., 2003. Comparison of changes in vegetation in northeast Greece with records of climate variability on orbital and suborbital frequencies over the last 450,000 years. Earth and Planetary Science Letters 212, 197-212.

Tzedakis, P.C., Hooghiemstra, H., Pälike, H., 2006. The last 1.35 million years at Tenaghi Philippon: revised chronostratigraphy and long-term vegetation trends. Quaternary Science Reviews, 25 (23-24), 3416-3430.

Waelbroeck, C., Labeyrie, L., Michel, E., Duplessy, J.C., McManus, J.F., Lambeck, K., Balbon, E., Labracherie, M., 2002. Sea-level and deep water temperature changes derived from benthic foraminifera isotopic records. Quaternary Science Reviews 21, 295-305.

Zhao, J.X., Hu, K., Xu, H., Collerson, K.D., 2001. Thermal ionization mass spectrometry U-Th dating of a hominid site in Nanjing, China. Geology 29, 27-30. 